\title{
PERANAN PETANI WANITA DALAM MENINGKATKAN PEREKONOMIAN KELUARGA DI DESA SAKRA SELATAN
}

\author{
Muhamad Zaril Gapari \\ STIT Palapa Nusantara Lombok NTB \\ zagap205@yahoo.co.id
}

\begin{abstract}
The purpose of this study is to know the role of women in improving family economy in the South Sakra Village, Sakra District East Lombok. Year. The type of research used in this study is research Qualitative descriptive. The data collection technique used is technique observation, documentation, and interviews. The results of the study indicate that there are several factors within socio-cultural life of the people of the Sakra Village south of Dasan Tereng Village which affects the women farmers to belp in life the family economy, namely: mutual cooperation and belp in the life of the farmer's family. and there are four important factors that become encouraging women of South Sakra Village farmers to take part in help the family's economic life, including: (1) environmental factors the availability of supporting facilities in the form of agricultural land and markets that can support in expanding marketing of agricultural products (2) economic factors, namely: the decreasing level of income of farmers, in the farming community Southern sakera village has three forms of the role of female farmers in life his family, namely: in family income, in financial management and in housebold settings. (3) family factors, namely: number dependents, the more the number of dependents the more you have to fulfilled. (4) education factor, which does not require higher education, so this work becomes an alternative. The form of the role of female farmers in improving the family economy in the South Hamlet Sakra Village Dasan Tereng has three things: (1) working in the agricultural sector, (2) working in the livestock sector, (3) working in the trade sector. Based on the things above women farmers in the southern sakera village have a dual role, namely public role and domestic role to help economic life bis family.
\end{abstract}

Keywords: the Role of Female Farmers

\begin{abstract}
Abstrak : Wanita sebagai bagian dari anggota keluarga seperti anggota keluarga yang lain mempunayai tugas dan fungsi yang sama dalam mendukung keluarga. Dari dulu sampai sekarang masih ada masyarakat yang menganggap bahwa tugas wanita dalam keluarga hanya melahirkan keturunan, mengasuh anak, melayani suami, dan mengurus anak. Tetapi dengan berkembangnya waktu ternyata tugas atau peranan wanita dalam kehidupan keluarga semakin bertambah dan berkembang lebih luas. Wanita saat ini tidak hanya melakukan kegiatan di dalam lingkup keluarga saja, tetapi di bidang-bidang kehidupan di masyarakat juga membutuhkan kehadiran wanita
\end{abstract}

Manazhim : Jurnal Manajemen dan Ilmu Pendidikan

Volume 1, Nomor 2, Agustus 2019; 1-11

https://ejournal.stitpn.ac.id/index.php/manazhim 
dalam kegiatan pekerjaannya. Tujuan penelitian ini adalah adalah untuk mengetahui peranan wanita dalam meningkatkan perekonomian keluarga di Desa Sakra Selatan Kecamatan Sakra Kabupaten Lombok Timur Tahun. Jenis penelitian yang digunakan dalam penelitian ini adalah penelitian Deskriptif kualitatif. Teknik pengumpulan data yang digunakan adalah teknik observasi, dokumentasi, dan wawancara. Hasil penelitian menunjukkan bahwa ada beberapa faktor dalam kehidupan sosial budaya masyarakat Desa sakra selatan Dusun Dasan Tereng yang ikut mempengaruhi para wanita petani untuk membantu dalam kehidupan ekonomi keluarganya, yaitu: kebiasaan gotong-royong dan tolong-menolong dalam kehidupan keluarga petani. dan ada empat faktor penting yang menjadi pendorong wanita petani Desa Sakra Selatan untuk ikut berperan dalam membantu kehidupan ekonomi keluarganya, meliputi: (1) faktor lingkungan terdapatnya sarana penunjang yang berupa lahan pertanian dan pasar yang bisa mendukung dalam perluasan pemasaran hasil pertanian (2) faktor ekonomi, yaitu: semakin menurunnya tingkat pendapatan petani, Pada masyarakat petani Desa sakra selatan terdapat tiga bentuk peranan wanita petani dalam kehidupan keluarganya, yaitu: dalam pendapatan keluarga, dalam pengelolaan keuangan dan dalam pengaturan kerumahtanggaan. (3) faktor keluarga yaitu : jumlah tanggungan, semakin banyak jumlah tanggungan semakin banyak yang harus dipenuhi. (4) faktor pendidikan yaitu tidak memerlukan pendidikan tinggi, sehingga pekerjaan ini menjadi alternative. Bentuk peranan petani wanita dalam meningkatkan perekonomian keluarga di Desa Sakra Selatan Dusun Dasan tereng ada tiga hal yaitu: (1) bekerja dalam sektor pertanian, (2) bekerja dalam sektor peternakan, (3) bekerja dalam sektor perdagangan. Berdasarkan hal di atas wanita petani di Desa sakra selatan mempunyai peran ganda, yaitu peran publik dan peran domestik untuk membantu kehidupan ekonomi keluarganya.

Kata Kunci: Peranan Petani Wanita.

\section{PENDAHULUAN}

Sejarah pembangunan di Indonesia memperlihatkan bahwa pembangunan sektor pertanian telah memberi kontribusi yang besar terhadap perubahan dalam perekonomian Indonesia. Pertanian juga memegang peranan penting dalam menyediakan bahan baku bagi sektor yang berkembang, menghemat devisa negara maupun sebagai tempat pasar bagi industri yang berkembang. Pembangunan pertanian bertujuan untuk meningkatkan pendapatan dan taraf hidup petani, pertumbuhan kesempatan kerja dan berusaha, meningkatkan gizi dan ketahanan pangan rumah tangga, dan mengentaskan kemiskinan di pedesaan. Semua ini berkaitan erat dengan peran, tugas, dan fungsi wanita di pedesaan. Berpedoman kepada pendapatan rumah tangga yang dapat dihasilkan oleh suami maupun istri (pola nafkah ganda), wanita memiliki peluang kerja yang dapat menghasilkan 
pendapatan bagi rumah tangganya, sebagai upaya mengurangi kemiskinan di pedesaan.

Wanita sebagai bagian dari anggota keluarga seperti anggota keluarga yang lain mempunayai tugas dan fungsi yang sama dalam mendukung keluarga. Dari dulu sampai sekarang masih ada masyarakat yang menganggap bahwa tugas wanita dalam keluarga hanya melahirkan keturunan, mengasuh anak, melayani suami, dan mengurus anak. Tetapi dengan berkembangnya waktu ternyata tugas atau peranan wanita dalam kehidupan keluarga semakin bertambah dan berkembang lebih luas. Wanita saat ini tidak hanya melakukan kegiatan di dalam lingkup keluarga saja, tetapi di bidang-bidang kehidupan di masyarakat juga membutuhkan kehadiran wanita dalam kegiatan pekerjaannya.

Keterlibatan perempuan secara umum disebabkan oleh dua hal besar, Pertama budaya atau kebiasaan yang berlangsung selama ini sehingga perempuan belum bisa berperan sesuai dengan kemampuan yang dimilikinya dan Kedua, adanya kendala pada perempuan itu sendiri secara tidak sadar yang merasa bahwa dirinya tidak harus berperan pada kegiatan-kegaitan tertentu yang semsetinya dapat dijalani secara lebih aktif dan dalam. ${ }^{1}$

Masyarakat adalah kesatuan hidup manusia yang berinteraksi menurut suatu sistem adat istiadat tertentu yang bersifat kontinyu dan terikat oleh suatu rasa identitas yang sama. Masyarakat disini khususnya di Desa Sakra Selatan, sebagian besar masyarakatnya berprofesi sebagai petani, maka rutinitasnya akan selalu bersentuhan dan berkaitan dengan kegiatan yang ada disawah.

Setelah peneliti melakukan observasi pada masyarakat Desa Sakra Selatan ditemukan beberapa hal yang menyebabkan rata-rata masyarakat tersebut berprofesi sebagai petani khususnya petani wanita yaitu bertani adalah lapangan kerja paling pokok untuk masyarakat Desa Sakra Selatan, penghasilan suami sebagai kepala keluarga belum bisa mencukupi kebutuhan keluarga, selain itu juga rata-rata wanita masyarakat Desa Sakra Selatan mendapatkan pendidikan yang masih relatif rendah yang disebabkan karna pernikahan usia dini. Sehingga peranan wanita di Desa Sakra Selatan tidak lepas tanggung jawabnya yaitu sebagai istri yang bertugas menyelesaikan

1 Meilia, Dwi, Peranan Petani Cengkeh Perempuan Sebagai Penunjang Perekonomian Keluarga di Desa Wonosalam. (Jombang: STKIP PGRI Jombang. Skripsi Tidak Di Terbitkan, Tahun 2013), 5. 
segala pekerjaan keluarga dan rumah tangga. Dari penguraian di atas bahwa para petani wanita yang ada di Desa Sakra Selatan mempunyai peran ganda baik sebagai ibu rumah tangga dan juga bekerja untuk mencari nafkah guna mencukupi kebutuhan hidup keluarga dan meningkatkan ekonomi keluarganya. Ikut sertanya anggota keluarga mencari nafkah merupakan upaya peningkatan pendapatan guna mengatasi masalah kebutuhan hidup rumah tangga. Namun demikian wanita juga diwajibkan sebagai warga Negara yang baik dan aktif dalam berbagai organisasi kewanitaan dan menyunjung karimya. Selain itu juga, faktor yang mendorong petani wanita ikut berperan dalam membantu kehidupan ekonomi keluarganya yakni ingin merubah hidup keluarga atau dengan kata lain keluar dari kemiskinan. Pada dasarnya yang dihadapi para petani wanita disetiap daerah adalah masalah yang sama yakni tingkat kehidupan yang relatif rendah. Maka dengan adanya permasalahan seperti yang dipaparkan di atas maka peneliti tertarik untuk meneliti para petani wanita khususnya di dearah Desa Sakra Selatan dengan judul "Peranan Petani Wanita Dalam Meningkatkan Perekonomian Keluarga Di Desa Sakra Selatan Kecamatan Sakra Kabupaten Lombok Timur".

\section{METODE PENELITIAN}

Jenis penelitian ini adalah penelitian kualitatif karena subjek yang diteliti adalah orang dengan segala aktivitasnya dan alam sekitarnya, penelitian kualitatif (qualitative research) adalah suatu penelitian yang ditujukan untuk mendeskripsikan dan menganalisis fenomena, peristiwa, aktivitas sosial, sikap, kepercayaan, persepsi, pemikiran orang secara individual maupun kelompok. ${ }^{2}$

Adapun yang menjadi tujuan penelitian ini adalah untuk mengetahui peranan wanita dalam meningkatkan perekonomian keluarga di Desa Sakra Selatan Kecamatan Sakra Kabupaten Lombok Timur.

Sampel yang digunakan dalam penelitian ini yaitu snowball sampling adalah teknik penentuan sampel yang mula-mula jumlahnya kecil, kemudian membesar. Ibarat bola salju yang menggelinding yang lama-lama menjadi besar. ${ }^{3}$ Dalam penentuan sampel, pertama-tama dipilih satu atau dua orang saja, tetapi karena

2 Sukmadinata, Nana Syaodih, Pendidikan Penelitian (Bandung: Remaja Rosdakarya, Tahun 2009), 69.

${ }^{3}$ Sugiyono, Metode Penelitian Kuantitatif Kualitatif dan R \& D. Bandung: ALFABET, Tahun 2009), 85. 
dengan dua orang ini belum merasa lengkap terhadap data yang diberikan, maka peneliti mencari orang lain yang dipandang lebih tahu dan dapat melengkapi data yang diberikan oleh dua orang sebelumnya. Begitu seterusnya, sehingga jumlah sampel semakin banyak. Jadi yang menjadi sampel dalam penelitian ini adalah semua petani wanita yang ada di kekadusan Dusun Dasan Tereng Desa Sakra Selatan.

Dalam melakukan penelitian ini maka peneliti menggukan beberapa teknik dalam pengumpulan data antara kain:

Wawancara atau interview (wawancara), jenis wawancara yang digunakan dalam penelitian ini adalah wawancara terstruktur yaitu wawancara yang dilakukan dengan terlebih dahulu membuat daftar pertanyaan yang kadang-kadang disertai dengan jawaban alternatifnya dengan maksud agar pengumpulan data dapat lebih terarah kepada tujuan penelitian dan pembuktian hipotesis Observasi atau yang disebut pula dengan pengamatan, meliputi kegiatan pemuatan perhatian terhadap sesuatu objek dengan menggunakan seluruh alat indra. Jadi, mengobservasi dapat dilakukan melalui penglihatan, penciuman, pendengaran, peraba, dan pengecap. Dokumentasi yang dimaksud disini adalah seperti foto/gambar, catatan-catatan lain yang berhubungan dengan fokus penelitian.

Adapun langkah-langkah yang diperlukan dalam menganalisis data antara lain: reduksi data, penyajian data dan penarikan kesimpulan atau verifikasi.

\section{HASIL PENELITIAN}

Adapun hasil dari penelitian ini dalam adalah kehidupan sosial budaya masyarakat petani di dusun dasan tereng desa sakra selatan,

1. Kehidupan Sosial Budaya Masyarakat Petani di Dusun Dasan Tereng Desa Sakra Selatan

Berdasarkan rencana yang telah di buat oleh peneliti maka daerah yang dipilih sebagai sampel adalah sebuah Dusun dalam wilayah Kecamatan Sakra Desa Sakra Selatan, yakni Dusun Dasan Tereng. Dipilihnya Dusun ini karena beberapa alasan antara lain: a) Terletak diwilayah kecamatan Sakra, sehingga mudah di jangkau. b) Serta masyakat sebagian besar berpropesi sebagai petani. Secara umum petani 
bertempat tinggal di pedesaan dan sebagian besar diantaranya terutama yang tinggal di daerah yang padat penduduk serta hidup dalam garis kemiskinan. ${ }^{4}$

Kondisi keseharian masyarakat Dusun Dasan Tereng dapat dikatakan menjadi seorang petani merupakan kegiatan turun temurun yang sudah dikerjakan, mengingat pekerjaan di sawah masih dikerjakan sampai sekarang. Dari setiap warga Dusun Dasan Tereng para petani rata-rata mempunyai lahan pertanian 7-20 are. Dari keadaan sosial masyarakat warga Dusun Dasan Tereng masih memegang sikap gotong royong serta sikap tolong menolong antar sesama. Sikap seperti ini dapat dilihat dalam kehidupan sehari-hari dari warga masyarakat Dusun Dasan Tereng dalam satu keluarga masih ada ikatan persaudaraan atau hubungan saudara. Adapun bentuk kerjasama dari masyarakatnya nampak pada adanya kegiatan-kegiatan seperti kegiatan pembuatan gorong-gorong atau parit untuk saluran air irigasi persawahan, upacara keagamaan, upacara adat, kegiatan di sawah dan kegiatan lainnya.

Mengingat dari keadaan alam ini maka, masyarakat di Dusun Dasan Tereng yang bekerja sebagai petani dan buruh tani. Dari sebagian besar penduduk Dusun Dasan Tereng kegiatan pertanian lebih di dominasi oleh para wanita atau yang sering kita kenal dengan sebutan petani wanita. Petani wanita Dusun Dasan Tereng merupakan wanita baik dia dewasa (sudah berkeluarga) dan muda yang bekerja di sawah. Mereka bisa sebagai ibu rumah tangga sekaligus menjadi petani.

Petani wanita Dusun Dasan Tereng dalam mengerjakan peranannya sebagai petani sama dengan petani wanita di daerah lain yaitu melakukan pembenihan sampai dengan pemanenan. Petani wanita di Dusun Dasan Tereng yakni berperan ganda dalam kehidupanya, Selain berperan di rumah atau keluarga petani Dusun Dasan Tereng berperan dalam pertanian bahkan mereka juga berperan dalam mencari nafkah seperti yang dilakukan oleh responden dengan menjual hasil pertaniannya dan memelihara hewan ternak yaitu ayam dan sapi.

Petani laki-laki dan petani wanita mempunyai keinginan yang sama yakni keinginan untuk maju dan sukses dalam usaha pertanian, tetapi keinginan kadang terhalang oleh kurangnya modal yang mereka miliki yang mengakibatkan banyak diantara mereka menyewakan lahan peraniannya kepada orang lain. Dengan tidak

\footnotetext{
${ }^{4}$ Raharti f, Petani Berdasi. (Jakarta : Swadaya, Tahun 1990), 32.
} 
adanya tempat bekerja, maka para petani wanita harus bisa berpropesi ganda menjadi buruh tani, peternak dan lainnya.

Keadaan seperti ini kita jumpai dari para petani lainnya. Seperti halnya yang dihadapi oleh para petani di Dusun Dasan Tereng yang mengakibatkan ikut berperan sertanya para petani wanita dalam mencari nafkah. Selain di pertanian petani wanita juga ikut berperan di bidang perdagangan yaitu dengan menjual hasil pertanian.

Berbicara tentang kehidupan dan permasalahan yang dihadapi oleh petani wanita pada umumnya yaitu kekurangan dalam memenuhi keperluan sehari-hari seperti sandang, dan pangan. kurangnya penghasilan dari suami yang mengakibatkan para petani wanita ikut bekerja. Untuk mencukupi serta meningkatkan ekonomi keluarganya, seperti yang dilakukan responden petani wanita di Dusun Dasan Tereng mengerjakan pekerjakan seperti kegiatan pertanian, berdagang, berternak dan kegiatan lainnya yang bisa menghasilkan uang. Inilah bentuk kegiatan yang dilakukan oleh wanita di Dusun Dasan Tereng serta alasan mereka sehingga petani wanita ikut bekerja mencari nafkah untuk keluarganya, para petani wanita berpartisifasi dalam meningkatkan ekonomi keluarga melalui ketenagakerjaan sehingga mengetahui sejauh mana mereka terlibat dalam kegiatan bekerja. Sebagai anggota keluarga petani wanita Dusun Dasan Tereng mempuyai kedudukan yang penting dalam kegiatan pertanian. Hal ini nampak pada keikutsertaan mereka dalam mencari nafkah dalam usaha tani sebagai petani bagi diri sendiri dan buruh tani bagi orang lain. Peran sebagai pekerja dapat dilihat dalam usaha tani yang menggambarkan perilaku petani wanita dengan mengeluarkan tenaga dan pikirannya dengan terlibat langsung dalam usaha pertanian untuk mencapai tujuan tertentu. Para wanita di percayai oleh laki-laki untuk mengurus keperluan pertanian karena para petani wanita lebih tekun, teliti, telaten, dalam pengelolaan pertanian. Oleh karena itu para istri atau petani wanita ini ikut terjun mencari nafkah. Selain bekerja disawah dalam memenuhi serta meningkatkan perekonomian keluarga para petani wanita mempunyai pekerjaan sampingan yakni bekerja dalam sektor pertanian, bekerja dalam sektor peternakan, bekerja dalam sektor perdagangan, serta bekerja dalam sektor industri. Jadi petani wanita adalah istri petani atau wanita desa baik dia dewasa maupun muda yang bekerja di sawah. ${ }^{5}$

${ }^{5}$ Mosse, cleves Julia, Gender dan pembangunan, (Yogyakarta : pustaka pelajar, Tahun 2007), 38-44. 
Petani wanita Dusun Dasan Tereng melakukan kegiatan pertaniannya sejak pagi hari setelah kegiatan atau peranannya sebagai wanita telah selesai yaitu mulai jam 07.00 sampai jam 11.30 istirahat, melanjutkan bekerja jam 02.00 sampai jam 05.15, seperti halnya yang dilakukan oleh responden, Terkadang kegiatan di sawah di lakukan berdua dengan petani laki-laki. Adapun jenis kegiatan yang di lakukan musih akhir tahun ini seperti memanenkan Tembako.

2. Faktor-Faktor Yang Mendorong Petani Wanita Ikut Bekerja di Dusun Dasan Tereng Desa Sakra Selatan

Faktor lingkungan, adanya lahan pertanian yang dimiliki hal ini nampak pula pada wilayah Dusun Dasan Tereng yang seluruh wilayahnya di kelilingi lahan pertanian. Adanya lahan pertanian yang ada di tempat tinggal mereka di sekitarnya memberikan keuntungan tersendiri bagi mereka yang tidak mempunyai lahan dan bagi mereka yang tidak bekerja. Dengan adanya lahan milik warga memberi kesempatan kerja bagi mereka yang bekerja sebagai buruh tani sehingga banyak para petani wanita yang ikut berperan, mengingat adanya lahan pertanian dalam menunjang dan memperdagangkan hasil pertanian, dengan ikut berperannya petani wanita nampak jelas pada kegiatan berdagang (menjadi pedagang) hasil pertanian.

Faktor ekonomi merupakan masalah yang paling utama yang di hadapi oleh semua individu lebih lagi bagi para petani yang hanya mengandalkan hasil tanaman semusim yang tidak menentu hasil pertaniannya. Dengan keadaan seperti ini masyarakat Dusun Dasan Tereng harus berusaha dalam mencukupi keperluan keluarga, salah satunya yaitu ikut bekerjanya para wanita baik dia menjadi petani, buruh tani, bahkan menjadi pedagang di rumah maupun di pasar untuk menambah penghasilannya. Hal ini berkaitan dengan sifat musim kegiatan di bidang pertanian. Pada umumnya keluarga petani membutuhkan pekerjaan di luar sektor pertanian untuk menambah penghasialannya. ${ }^{6}$ Perempuan petani juga harus diberi kesempatan untuk dapat ikut dalam kelompok-kelompok ekonomi dan sosial yang bertujuan untuk meningkatkan potensi ekonomi dan sosial rumah tangga petani, misalnya: kelompok petani atau kelompok koprasi. ${ }^{7}$

${ }^{6}$ Mubyarto. Pengantar Ekonomi Pertanian/Mubyarto, (Jakarta: LP3ES. Tahun 1985), 45.

${ }^{7}$ Http:/ / Org-Perekonomian-Akses-kesejabteraaan/perempuan-ilmu ekonom, Di akses tanggal 17 September 2013. Pukul 12.15 
Faktor keluarga, yaitu Jumlah tanggungan adalah jumlah anak, istri, dan anggota keluarga lainnya, yang dinafkahi oleh petani yang nantinya sangat berpengaruh terhadap pendapatan dan dalam memenuhi kebutuhan keluarga. Semakin banyak jumlah tanggungan keluarga maka semakin banyak pula kebutuhan yang harus dipenuhi dan semakin tinggi tingkat pendapatan yang dibutuhkan. Sementara, di Dusun Dasan Tereng jumlah penghasilan para petani laki-laki masih tergolong rendah, penghasilan dari para petani laki-laki yang ada di Dusun Dasan Tereng tidak mempunyai pekerjaan yang tetap, mereka hanya bekerja sebagai petani, pedagang, peternak dan buruh. Maka untuk dapat menafkahi keluarga tidak jarang suami mengikut sertakan istri dan anaknya untuk bekerja menjadi petani.

Pendidikan kaum wanita di Desa Dusun Dasan Tereng rata-rata berpendidikan SD, SMP, SMA dan ada beberapa yang melanjutkan ke perguruan tinggi. Bagi mereka yang hanya berpendidikan SD-SMP, biasanya memilih pekerjaan di sektor informal seperti menjadi pedagang, buruh bangunan, petani dan buruh tani. Menjadi petani, para kaum wanita tanpa perlu memiliki keahlian khusus, karena mereka bisa mengerjakan pekerjaan ini pengaruh lingkungan yang dari kecil telah bergelut di bidang pertanian.

\section{Interpretasi}

Sebagai seorang wanita, istri dan ibu bagi anaknya dengan adanya kegiatan tersebut tidak melupakan peranannya dalam lingkungan keluarga. Adapun peran yang dilakukan sama seperti wanita pada umumnya, seperti menyiapkan makanan bagi anak dan suaminya, menyelesaikan pekerjaan, menyiapkan keperluan dan perlengkapan anak sekolah. Diantaranya ikut berperan sebagai petani atau berusaha dalam sektor pertanian, kegiatan ini di dukung dengan adanya lahan pertanian yang dia miliki. Dari luas lahan yang mereka miliki yakni rata-rata 7-20 are. Dengan adanya lahan pertanian ini memberi tambahan dalam memenuhi kebutuhan keluarga Kegiatan ini mereka lakukan bersama suaminya. Selain di bidang pertanian petani wanita juga berperan dalam bidang perdagangan yaitu dengan mendistribusikan hasil pertanian ke konsumen dan bidang perternakan yang memelihara hewan ternak seperti ayam, bebek, kambing dan sapi. Ada dua tipe peranan wanita yaitu: Pola peranan digambarkan wanita seluruhnya hanya dalam pengerjaan pekerjaan rumah tangga atau pekerjaan pemeliharaan kebutuhan hidup semua anggota keluarga dan 
rumah tangganya. Pola wanita memiliki peran ganda yaitu: sebagai pengurus rumah tangga dan mencari nafkah. ${ }^{8}$

Keterlibatan mereka dalam membantu ekonomi keluarga sudah biasa dilakukan dan secara turun temurun telah dilakukan oleh perempuan. Mereka harus berperan ganda, disamping memikirkan rumah tangga, melakukan pekerjaan sebagai petani, mereka juga melakukan pekerjaan lain diluar pertanian. Mereka seakan tidak pernah mempersoalkan peran ganda yang dilakukan karena telah terbiasa mencari nafkah sebagai pendapatan tambahan. Langkah ini dilakukan oleh petani wanita karena hasil produksi lahan pertanian tidak dapat mencukupi kebutuhan hidup sehari-hari dan juga untuk membiayai keperluan anak-anak mereka.

\section{KESIMPULAN}

Berdasarkan hasil penelitian maka dapat disimpulkan bahwa: Peranan petani wanita di Dusun Dasan Tereng Desa Sakra Selatan, sangat besar baik dalam tugasnya sebagai ibu rumah tangga maupun dalam meningkatkan prekonomian keluarga yang dapat dilihat dari tiga sektor yaitu: (a) Sektor Pertanian, pertanian petani wanita ikut serta dalam mencari nafkah di usaha tani baik sebagai petani di lahan sendiri ataupun sebagai buruh tani dilahan orang lain yang nantinya akan mendapatkan upah dan bisa meningkatkan prekonomian keluarga. (b) Sektor Perdagangan, peran petani wanita selain menjadi petani, para petani wanita juga mempunyai peran aktif dalam sektor perdagangan seperti mendistribusikan hasil pertanian ke konsumen. (c). Sektor Perternakan, selain disektor pertanian dan perdagangan petani wanita Dusun Dasan Tereng juga ikut berpartisipasi dalam meningkatkan prekonomian keluarga dengan bergelut dalam sektor perternakan yaitu dengan memelihara hewan ternak seperti ayam, bebek, kambing dan sapi.

\section{SARAN}

Di harapkan dari hasil penelitian ini dapat memberikan infornasi penting kepada pemerintah desa, keluarga serta masyarakat mengenai peran petani wanita dalaam meningkatkan prekonomian keluarga. Pemerintah desa di harapkan

${ }^{8} \mathrm{Http}: / /$ Karya - ilmiah.um.ac. id/ index.php/ sejarab/article/ view/734, Di akses tanggal 25 september 2013 pukul 08.35 
memberikan perhatian khusus untuk kesejahteraan para petani wanita karena terkait dengan sebagian besar warga di Sakra Selatan wanita ikut berperan sebagai petani dalam meningkatkan prekonomian keluarga. Pemerintah dapat memberikan program-program atau pelatihan-pelatihan terhadap petani wanita dalam meningkatkan kemampuan di bidang pertanian agar dapat mengelola lahan pertaniandan bekerja dengan lebih efektif dan efisien.

\section{DAFTAR PUSTAKA}

Meilia, Dwi, (2013). Peranan Petani Cengkeh Perempuan Sebagai Penunjang Perekonomian Keluarga di Desa Wonosalam. Jombang: STKIP PGRI Jombang. Skripsi Tidak Di Terbitkan.

Mosse, cleves Julia, (2007). Gender dan pembangunan Yogyakarta: pustaka pelajar.

Mubyarto, (1985). Pengantar Ekonomi Pertanian/Mubyarto, Jakarta: LP3ES

Raharti f. 1990. Petani Berdasi. Jakarta: Swadaya

Sukmadinata, Nana Syaodih, (2009). Pendidikan Penelitian, Bandung: PT. Remaja Rosdakarya.

Sugiyono, (2009). Metode Penelitian Kuantitatif Kualitatif dan $\mathrm{R} \& \mathrm{D}$. Bandung: ALFABET

Http:// Org-Perekonomian-Akses-kesejabteraaan/perempuan-ilmuekonomi, Di akses tanggal 17 September 2013. Pukul 12.15.

Http:// Karya-ilmiah.um.ac.id/index.php/sejarah/article/view/734, Di akses tanggal 25 september 2013 pukul 08.35. 